\title{
Octennial Review (2010-2018) of Literature on M- Learning for Promoting Distributed-Based Medical Education in Sub-Saharan Africa
}

Abdullahi Abubakar Yunusa',2, Irfan Naufal Umar'2, and Brandford Bervell ${ }^{2,3}$

${ }^{1}$ Usmanu Danfodiyo University Sokoto, Nigeria., ${ }^{2}$ Centre for Instructional Technology and Multimedia. Universiti Sains

Malaysia, Malaysia., ${ }^{3}$ College of Distance Education, University of Cape Coast, Ghana

\begin{abstract}
Medical education in Africa is in desperate need of reforms, evident in widespread diseases, and an inability to mobilise and train the required medical workforce to deal with these health issues. However, the exponential rise in the use of mobile technologies due to the spread of the Internet and increased telecommunication networks offer an opportunity for the transformation of medical education and practice through the deployment of mobile devices as a medium for learning and conveying health care services to the remote and resource-constrained locations of Sub-Saharan Africa (SSA). This paper reviewed articles on the affordances of m-learning for distributed medical education in SSA published between 2010-2018. Results from 18 articles identified in the review revealed a slow-paced ascendancy of practice and research in the field; it further exposed competing priorities, infrastructural deficit, and chronic workforce shortages as the bane of m-learning implementation in the subregion. This paper makes recommendations that will enhance the growth of mobile-based distance medical education and practice in SSA.
\end{abstract}

Keywords: mobile learning, distributed learning, medical education, Sub-Saharan Africa 


\section{Introduction}

Globally, the advent of the Internet has led to a progressive transformation in all facets of human activities. Amongst these, is the impact of Internet-driven technologies that have reshaped the educational landscape. It has become apparent that the traditional form of teaching and learning confined to the classroom is no longer efficient due to limited out of class collaboration and inadequate infrastructure (Africa-America Institute (AAI), 2015; Organisation for Economic Co-operation and Development (OECD), 2009). However, electronic learning (e-learning) has the affordances to accommodate more people, especially those with limited access to regular schooling (Yunusa \&Dalhatu, 2014) as an alternative medium to education. The increasing rate of the remote and mobile workforce has resulted in the emergence of the use of mobile technologies for communication, collaboration, and exchange of occupational knowledge practices and training. Consequently, this has evolved into various forms of technology-enhanced learning solutions across human endeavour and the ubiquity of mobile devices for mobile learning is now potentially more revolutionary than e-learning (Okai-Ugbaje, Ardzejewska, \&Ahmed, 2017).

Keegan (as cited in Ally, 2009) predicted that the future of mobile learning is "wireless," and today virtually all human activities are gradually transforming into online using several mobile devices and platforms. Sub-Saharan Africa (SSA) has the most significant number of adolescents and young adults in the world. The International Telecommunication Union (ITU) report (2016) on mobile cellular penetration indicate a mobile penetration rate of $65 \%$ in SSA. Relatedly, Masita-Mwangi, Mwakaba, Ronoh-Boreh and Impio (2012) note that 43\% of the population in SSA is below the age of 15 years making the region the youngest region in the world. Consequent upon which many African countries are making efforts in widening access and creating opportunities for the expansion of the Higher Education institutions to accommodate these young adults. However, these efforts are ineffective due to the rising number of students with an average of $50 \%$ more students per professor in African universities compared to the global average AAI (as cited in Bervell \& Umar, 2017).

One key aspect of education in sub-Saharan Africa that needs a technological intervention due to the problem above is medical education. The use of mobile learning offers opportunities for training more medical staff and promoting distance-based medical practices in Sub-Saharan Africa. Recently, authors such as Chaya, Pilot, and Urassa (2018); Lazarus, Sookrajh, and Satyapal (2017a) and Witt et al. (2016) had echoed the need for reforms in medical education and practice in SSA when they suggested the mobile learning paradigm. Recognising the need for mobile learning, these African medical practitioners have suggested that the adoption of mobile technologies and online courses will enable class sizes to increase dramatically in a short space of time and could potentially be significant in mobilising a medical workforce that is struggling with traditional modalities that cannot produce the desired results. The growth of these technologies across the world and Africa, in particular, has prompted some studies on the use of mobile devices in medical education in SSA (Adebara, Adebara, Olaide, Emmanuel, \& Olanrewaju, 2017; Chaya, Pilot, \& Urassa, 2018; Frehywot et al., 2013; Ibrahim, Salisu, Popoola, \&Ibrahim 2014; Lazarus, Sookrajh, \& Satyapal, 2017b; Masika et al., 2015; Witt et al., 2016b).

Koole (2009) defines mobile learning as "a process resulting from the convergence of mobile technologies, human learning capacities, and social interaction" (p.25). Accordingly, this definition placed m-learning within four central constructs namely, technological tools, context and social interactions buttressed by Krull and Duart (2017) and Naismith, Lonsdale, Vavoula, and Sharples 
(2004). Tsinakos and Ally (2013) explain m-learning as "the processes of coming to know through conversations across multiple contexts amongst people and personal interactive technologies" (p. 225). Mobile medical education referred to as mobile health education (m-health) is the process in which smartphones are used to help educate and inform students in the medical field (Ayemoba, 2017). According to Urassa et al. (2018), m-health is an emerging trend in the Health Information System, and defined as the use of mobile technology, such as cellular phones, wireless devices, or radio frequency identification tags, for health care or health services.

Despite the growing amount of research on m-learning in Higher Education across the world (Kaliisa \& Picard, 2017; Koole, 2009; Krull \& Duart 2017; Tsinakos \& Ally, 2013) there are few studies on its use in promoting medical education and practice in Sub-Saharan Africa. The World Health Organization (WHO) (2011) conducted a global survey on the explosion of $\mathrm{m}$-health and telemedicine activities around the world. Even though the report provided some extracts on efforts at using mobile technologies to deliver health services and information to remotely located and resource-constrained communities, the outcome of this report indicated that out of the 114 countries surveyed, SSA had the least positive indices on initiatives in m-learning in medical education (WHO, 2011). Against this background, this paper reviewed published articles based on studies carried out in the subregion between 2010-2018, bringing to fore the trends, milestones, and barriers to effective implementation of mobile technology-based learning solutions in medical education and contributes a reference that will guide policy and practice in the subregion.

Forthrightly, the study sought to answer the following questions:

1. What is the distribution of studies in m-learning initiatives in Sub-Saharan Africa?

2. What are the research models and designs reported in articles on m-learning in medical education and practice in Sub-Saharan Africa?

3. What are the methodologies used to investigate m-learning in medical education and practice in SSA?

4. What are the determinant factors reported in m-learning studies in medical education in SSA?

5. What are the barriers to effective implementation of m-learning in medical education and practice in Sub-Saharan Africa?

\section{Methodology}

This review followed the Preferred Reporting Items for Systematic Reviews and Meta-Analyses (PRISMA) protocol by Moher, Liberati, Tetzlaff, Altman, and Prisma Group. (2009). The PRISMA protocol is a step-by-step process to search, collect, analyse, synthesise, and report findings from the literature (see Figure 1). The first step was to search databases for studies on Mobile learning and Medical Education research in SSA. Search terms such as "m-learning," "m-health," "e-health," "mobile technologies," "medical education," "telemedicine," "adoption," "implementation," "mobile learning," and "Africa," were explored in prominent databases such as Google Scholar, Science Direct, Scopus, IEEE, PubMed, Microsoft Academic, and Institutional database. Reference pages of retrieved articles were screened for relevant studies for the review materials. The obtained articles were then sorted based 
on inclusion, exclusion, and eligibility criteria, and set out for the review (see Table 1). While, Table 2 depicts the summary of the reviewed studies.

Table 1

Eligibility Criteria for the Systematic Review of Studies of M-Learning in Medical Education in SSA

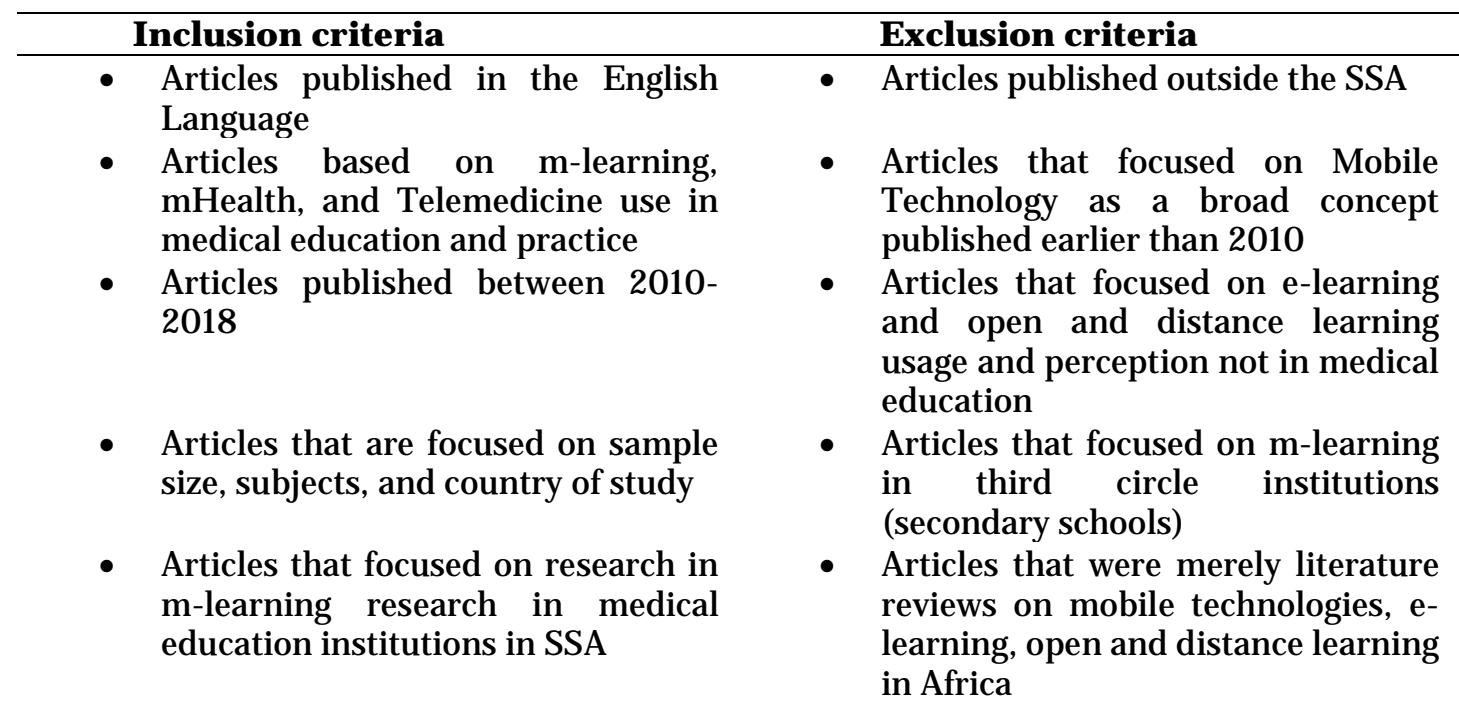

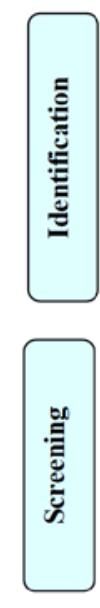

Google Scholar-1,547

Science Direct -356

Scopus -58

IEEEXplore-27

Microsoft Academic-08

USM Integrated-18

$(\mathrm{n}=\mathbf{2 , 0 2 7})$

Additional records identified

through other sources

( $\mathrm{n}=13)$

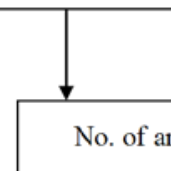

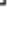
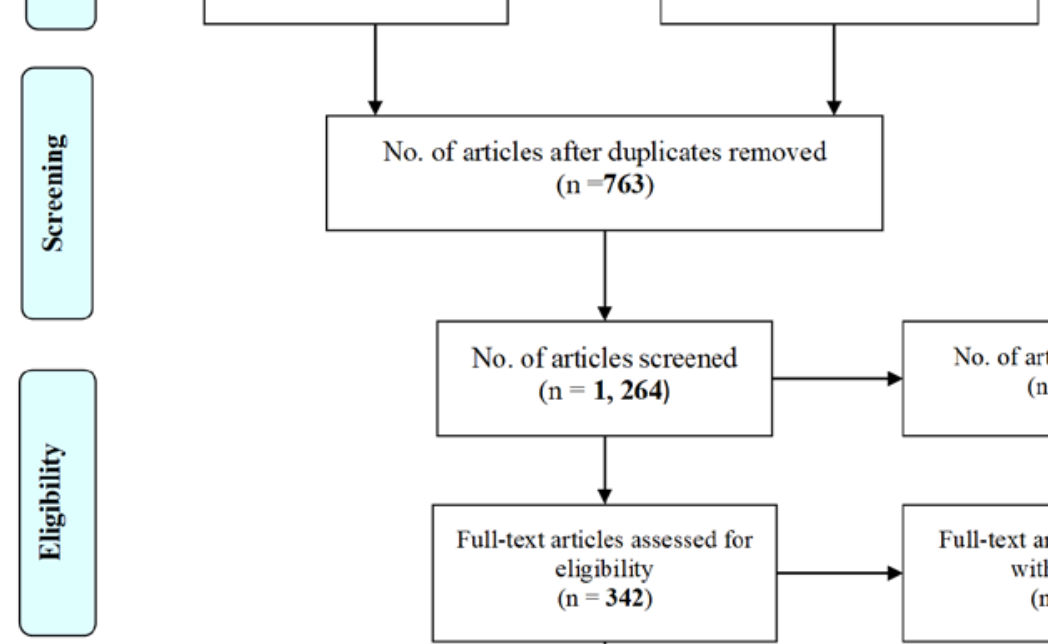

No. of articles screened $(\mathrm{n}=1,264)$

No. of articles excluded $(\mathrm{n}=922)$
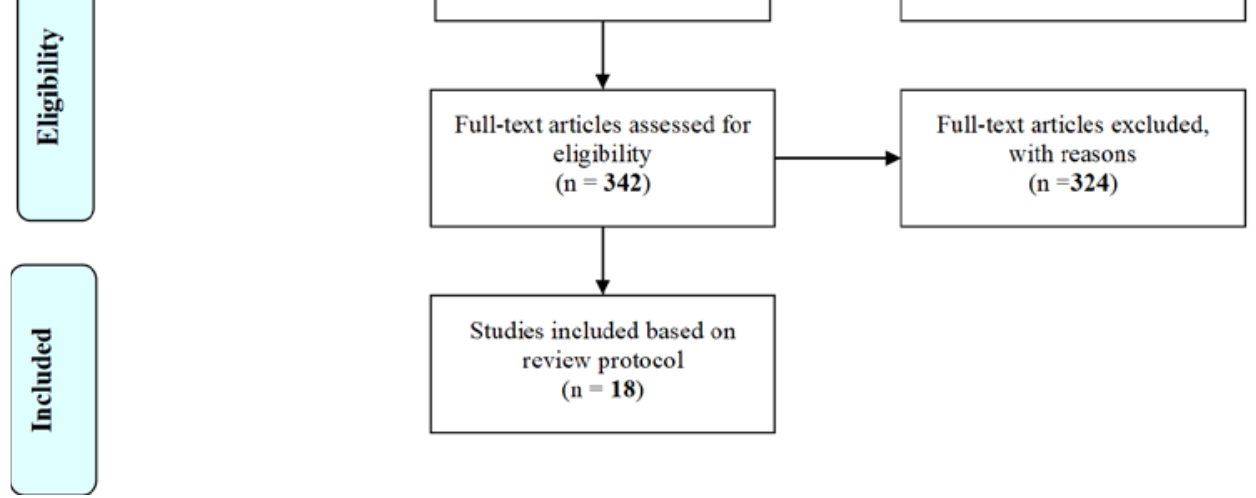

Figure 1. PRISMA article selection flowchart. 


\section{Analysis}

Coding technique

1. Country: The articles were sorted based on the context of the studies and classified according to the geographical location of the subregion.

2. Design of the study: The review focused on three broad study designs namely; qualitative, quantitative, and mixed method (Creswell, 2013).

3. Theoretical framework: The review focused on the theories adopted or adapted for the studies on m-learning in medical education in sub-Saharan Africa.

4. Sample size: The sample size of subjects grouped into; small, medium, and large. coded as ( $\leq 150=$ small), $(>150 \leq 250=$ medium $)$, and $(>250=$ Large $)$.

5. Subjects of the study: Subjects were; instructors, students (Interns), nurses, other health professionals or both.

6. Statistical tools: Instruments employed for data analysis were; qualitative thematic/narrative (Creswell,2013) and experimental and pilot studies; descriptive statistics; correlation, regression/General Linear Models / MANOVA; and Structural Equation Modelling techniqueSEM (Kline, 2015).

7. Effective factors (milestones): significant achievements and factors determining the use of $\mathrm{m}$ learning based on the findings of the studies.

8. Challenges: Challenges outlined by the findings of the studies in the use, adoption, or implementation of m-learning in medical education in thematic areas; system related; IT infrastructure; skills/training; technical support; leadership/management support; policy issues; personal issues; e-content/ e-curriculum; and time constraints.

Table 2

Summary of Reviewed Studies

\begin{tabular}{|l|l|l|l|l|l|}
\hline $\begin{array}{l}\text { Author/ } \\
\text { date }\end{array}$ & Paper title & Country & $\begin{array}{l}\text { Research design } \\
\text { \& instrument }\end{array}$ & $\begin{array}{l}\text { Sample \& } \\
\text { subjects }\end{array}$ & $\begin{array}{l}\text { Statistical analysis } \\
\text { adopted in the } \\
\text { studies }\end{array}$ \\
\hline $\begin{array}{l}\text { Adebara et } \\
\text { al. (2017) }\end{array}$ & $\begin{array}{l}\text { Knowledge, } \\
\text { Attitude and } \\
\text { Willingness to Use } \\
\text { mHealth } \\
\text { Technology Among } \\
\text { Doctors at a Semi- } \\
\text { urban Tertiary } \\
\text { Hospital in Nigeria }\end{array}$ & Nigeria & $\begin{array}{l}\text { Quantitative. } \\
\text { Questionnaire. }\end{array}$ & $\begin{array}{l}220 \text { medical } \\
\text { doctors. }\end{array}$ & $\begin{array}{l}\text { Descriptive and } \\
\text { inferential statistics } \\
\text { (Chi-square). }\end{array}$ \\
\hline
\end{tabular}




\begin{tabular}{|c|c|c|c|c|c|}
\hline $\begin{array}{l}\text { Anokwa } \\
\text { (2010) }\end{array}$ & $\begin{array}{l}\text { Delivering Better } \\
\text { HIV Care in Sub- } \\
\text { Saharan Africa } \\
\text { Using Phone-Based } \\
\text { Clinical Summaries } \\
\text { and Reminders }\end{array}$ & $\begin{array}{l}\text { Sub- } \\
\text { Saharan } \\
\text { Africa } \\
\text { (SSA; } \\
\text { Kenya). }\end{array}$ & $\begin{array}{l}\text { Design of software } \\
\text { framework that } \\
\text { delivers summaries } \\
\text { and reminders to } \\
\text { HIV patients. }\end{array}$ & $\begin{array}{l}4,500 \\
\text { patients. }\end{array}$ & $\begin{array}{l}\text { Thematic narrative } \\
\text { analysis. }\end{array}$ \\
\hline $\begin{array}{l}\text { Aryee } \\
(2014)\end{array}$ & $\begin{array}{l}\text { The Role of Mobile } \\
\text { Phones in Health } \\
\text { Education for } \\
\text { Rural Communities } \\
\text { in Ghana: An } \\
\text { Exploratory Study } \\
\text { in Digital } \\
\text { Technologies }\end{array}$ & Ghana & $\begin{array}{l}\text { Mixed Method } \\
\text { (Questionnaire and } \\
\text { interviews). }\end{array}$ & $\begin{array}{l}92 \text { health } \\
\text { workers. }\end{array}$ & Descriptive statistics. \\
\hline $\begin{array}{l}\text { Barteit et } \\
\text { al. (2015) }\end{array}$ & $\begin{array}{l}\text { Self-Directed E- } \\
\text { Learning at a } \\
\text { Tertiary Hospital in } \\
\text { Malawi -A } \\
\text { Qualitative } \\
\text { Evaluation \& } \\
\text { Lessons Learnt }\end{array}$ & Malawi & $\begin{array}{l}\text { Qualitative study, } \\
\text { using face-to-face } \\
\text { interviews, guided } \\
\text { group discussions, } \\
\text { and observations. }\end{array}$ & $\begin{array}{l}14 \text { medical } \\
\text { doctors, } \\
\text { interns, and } \\
\text { clinical } \\
\text { officers. }\end{array}$ & Narrative analysis. \\
\hline $\begin{array}{l}\text { Bediang et } \\
\text { al. (2013) }\end{array}$ & $\begin{array}{l}\text { Computer Literacy } \\
\text { and E-learning } \\
\text { Perception in } \\
\text { Cameroon: The } \\
\text { Case of Yaounde } \\
\text { Faculty of Medicine } \\
\text { and Biomedical } \\
\text { Sciences }\end{array}$ & Cameroon & $\begin{array}{l}\text { Quantitative. } \\
\text { Questionaire. }\end{array}$ & $\begin{array}{l}307 \text { students, } \\
\text { residents, and } \\
\text { lecturers. }\end{array}$ & $\begin{array}{l}\text { Descriptive statistics } \\
\text { and chi-square. }\end{array}$ \\
\hline $\begin{array}{l}\text { Biruk, } \\
\text { Yilma, } \\
\text { Andualem, } \\
\text { \&Tilahun } \\
\text { (2014) }\end{array}$ & $\begin{array}{l}\text { Health } \\
\text { Professionals } \\
\text { Readiness to } \\
\text { Implement an } \\
\text { Electronic Medical } \\
\text { Record System at } \\
\text { Three Hospitals in } \\
\text { Ethiopia: A Cross- } \\
\text { Sectional Study }\end{array}$ & Ethiopia & $\begin{array}{l}\text { Quantitative Cross- } \\
\text { sectional design. } \\
\text { Questionnaire. }\end{array}$ & $\begin{array}{l}606 \text { medical } \\
\text { health } \\
\text { professionals. }\end{array}$ & $\begin{array}{l}\text { Descriptive statistics, } \\
\text { bivariate, and } \\
\text { multivariate logistic } \\
\text { regression. }\end{array}$ \\
\hline $\begin{array}{l}\text { Chang et al. } \\
\text { (2012a) }\end{array}$ & $\begin{array}{l}\text { Smartphone-Based } \\
\text { Mobile Learning } \\
\text { With Physician } \\
\text { Trainees in } \\
\text { Botswana }\end{array}$ & Botswana & $\begin{array}{l}\text { Quasi-experimental } \\
\text { design. }\end{array}$ & $\begin{array}{l}\text { Trainee } \\
\text { physicians } \\
\text { (sample not } \\
\text { specified) }\end{array}$ & Descriptive statistics. \\
\hline
\end{tabular}




\begin{tabular}{|c|c|c|c|c|c|}
\hline $\begin{array}{l}\text { Chang et al. } \\
(2012 b)\end{array}$ & $\begin{array}{l}\text { Use of Mobile } \\
\text { Learning by } \\
\text { Resident } \\
\text { Physicians in } \\
\text { Botswana }\end{array}$ & Botswana & $\begin{array}{l}\text { Quantitative. } \\
\text { questionnaire. }\end{array}$ & $\begin{array}{l}\text { Seven resident } \\
\text { physicians }\end{array}$ & $\begin{array}{l}\text { Descriptive statistics, } \\
\text { and narrative } \\
\text { analysis. }\end{array}$ \\
\hline $\begin{array}{l}\text { Feldacker } \\
\text { et al. (2017) }\end{array}$ & $\begin{array}{l}\text { Continuing } \\
\text { Professional } \\
\text { Development for } \\
\text { Medical, Nursing, } \\
\text { and Midwifery. } \\
\text { Cadres in Malawi, } \\
\text { Tanzania and } \\
\text { South Africa: A } \\
\text { Qualitative } \\
\text { Evaluation }\end{array}$ & $\begin{array}{l}\text { SSA } \\
\text { (Malawi, } \\
\text { Tanzania, } \\
\text { and South } \\
\text { Africa) }\end{array}$ & $\begin{array}{l}\text { Mixed method } \\
\text { (focus group } \\
\text { discussion [FGD], } \\
\text { key informant } \\
\text { interview, and } \\
\text { questionnaire). }\end{array}$ & $\begin{array}{l}89 \text { healthcare } \\
\text { workers. }\end{array}$ & Descriptive statistics. \\
\hline $\begin{array}{l}\text { Gupta, } \\
\text { Marsden, } \\
\text { Oluka, } \\
\text { Sharma, \& } \\
\text { Lucas } \\
\text { (2017) }\end{array}$ & $\begin{array}{l}\text { Lessons Learned } \\
\text { from Implementing } \\
\text { E-Learning for the } \\
\text { Education of } \\
\text { Health } \\
\text { Professionals in } \\
\text { Resource- } \\
\text { Constrained } \\
\text { Countries }\end{array}$ & Uganda & $\begin{array}{l}\text { Qualitative, using a } \\
\text { case study approach } \\
\text { (key informant } \\
\text { interviews). }\end{array}$ & $\begin{array}{l}\text { Three } \\
\text { universities in } \\
\text { Uganda. }\end{array}$ & $\begin{array}{l}\text { Thematic narrative } \\
\text { analysis. }\end{array}$ \\
\hline $\begin{array}{l}\text { Ibrahim et } \\
\text { al. (2014) }\end{array}$ & $\begin{array}{l}\text { Use of } \\
\text { Smartphones } \\
\text { Among Medical } \\
\text { Students in the } \\
\text { Clinical Years at a } \\
\text { Medical School in } \\
\text { Sub-Sahara Africa: } \\
\text { A Pilot Study }\end{array}$ & Nigeria & $\begin{array}{l}\text { Quantitative cross- } \\
\text { sectional study. } \\
\text { Questionnaire. }\end{array}$ & $\begin{array}{l}123 \text { medical } \\
\text { students. }\end{array}$ & Descriptive statistics. \\
\hline $\begin{array}{l}\text { Lazarus, et } \\
\text { al. (2017) }\end{array}$ & $\begin{array}{l}\text { Tablet Technology } \\
\text { in Medical } \\
\text { Education in South } \\
\text { Africa: A Mixed } \\
\text { Methods Study }\end{array}$ & $\begin{array}{l}\text { South } \\
\text { Africa }\end{array}$ & $\begin{array}{l}\text { Mixed method/ } \\
\text { questionaire, (open } \\
\text { and closed-ended). }\end{array}$ & $\begin{array}{l}178 \text { medical } \\
\text { students. }\end{array}$ & $\begin{array}{l}\text { Descriptive statistics } \\
\text { and thematic } \\
\text { analysis. for the open- } \\
\text { ended questionnaire. }\end{array}$ \\
\hline $\begin{array}{l}\text { Masika et } \\
\text { al. (2015) }\end{array}$ & $\begin{array}{l}\text { Use of Mobile } \\
\text { Learning } \\
\text { Technology Among } \\
\text { Final Year Medical } \\
\text { Students in Kenya }\end{array}$ & Kenya & $\begin{array}{l}\text { Cross-sectional } \\
\text { descriptive study. }\end{array}$ & $\begin{array}{l}292 \text { medical, } \\
\text { nursing, } \\
\text { pharmacy, } \\
\text { and dental } \\
\text { students. }\end{array}$ & $\begin{array}{l}\text { Chi-square and t-test } \\
\text { for bivariate analysis } \\
\text { (regression). }\end{array}$ \\
\hline $\begin{array}{l}\text { Obi et al. } \\
\text { (2018) }\end{array}$ & $\begin{array}{l}\text { E-Learning } \\
\text { Readiness From } \\
\text { Perspectives of } \\
\text { Medical Students: } \\
\text { A Survey in Nigeria }\end{array}$ & Nigeria & $\begin{array}{l}\text { Quantitative cross- } \\
\text { sectional survey. } \\
\text { Questionnaire. }\end{array}$ & $\begin{array}{l}284 \text { medical } \\
\text { students. }\end{array}$ & $\begin{array}{l}\text { Descriptive statistics, } \\
\text { analysis of variance } \\
\text { (ANOVA), } \\
\text { correlation, and } \\
\text { multiple regression. }\end{array}$ \\
\hline
\end{tabular}




\begin{tabular}{|c|c|c|c|c|c|}
\hline $\begin{array}{l}\text { Olajubu, } \\
\text { Odukoya, } \\
\& \\
\text { Akinboro, } \\
(2014)\end{array}$ & $\begin{array}{l}\text { LWAs } \\
\text { Computational } \\
\text { Platform for E- } \\
\text { Consultation Using } \\
\text { Mobile Devices: } \\
\text { Cases From } \\
\text { Developing } \\
\text { Nations }\end{array}$ & Nigeria & $\begin{array}{l}\text { Experimental study, } \\
\text { the design, } \\
\text { development, and } \\
\text { testing of a light } \\
\text { weight agent (lwa) } \\
\text { in mobile devices } \\
\text { used for medical e- } \\
\text { consultation in } \\
\text { vulnerable areas of } \\
\text { SSA. }\end{array}$ & $\begin{array}{l}\text { Sample and } \\
\text { subjects not } \\
\text { specified. }\end{array}$ & Descriptive narrative. \\
\hline $\begin{array}{l}\text { Pimmer et } \\
\text { al. (2014) }\end{array}$ & $\begin{array}{l}\text { Informal Mobile } \\
\text { Learning in Nurse } \\
\text { Education and } \\
\text { Practice in Remote } \\
\text { Areas: A Case } \\
\text { Study From Rural } \\
\text { South Africa }\end{array}$ & $\begin{array}{l}\text { South } \\
\text { Africa }\end{array}$ & $\begin{array}{l}\text { Qualitative study } \\
\text { (interview and } \\
\text { content analysis). }\end{array}$ & $\begin{array}{l}16 \text { nurses, } \\
\text { facilitators, } \\
\text { and clinical } \\
\text { managers. }\end{array}$ & $\begin{array}{l}\text { Qualitative content } \\
\text { analysis. }\end{array}$ \\
\hline $\begin{array}{l}\text { Urassa et } \\
\text { al. (2018) }\end{array}$ & $\begin{array}{l}\text { Addressing } \\
\text { Knowledge Gaps } \\
\text { among Nurses in } \\
\text { Health Care in } \\
\text { Tanzania: Use of } \\
\text { Mearning } \\
\text { Platforms in } \\
\text { Tanzania }\end{array}$ & Tanzania & $\begin{array}{l}\text { Mixed method, } \\
\text { questionnaire, and } \\
\text { interview }\end{array}$ & $\begin{array}{l}428 \text { active and } \\
\text { dormant } \\
\text { mobile-device } \\
\text { users among } \\
\text { nurses, and } \\
\text { nursing } \\
\text { officers. }\end{array}$ & Descriptive statistics. \\
\hline $\begin{array}{l}\text { Witt et al. } \\
(2016)\end{array}$ & $\begin{array}{l}\text { The Role of Tablets } \\
\text { in Accessing } \\
\text { Information } \\
\text { Throughout } \\
\text { Undergraduate } \\
\text { Medical Education } \\
\text { in Botswana }\end{array}$ & Botswana & Mixed method. & $\begin{array}{l}82 \\
\text { undergraduate } \\
\text { medical } \\
\text { students. }\end{array}$ & Descriptive statistics. \\
\hline
\end{tabular}

*Note. Refer to the reference list for the full details of the publications in the table.

\section{Results}

\section{Countries and Parts of Sub-Saharan Africa That Contributed to M-Learning Studies in Medical Education and Practice}

Table 3 presents the results on the geographical spread of articles on m-learning in medical education in Sub-Saharan Africa:

Table 3

Spread of Articles on M-Learning, M-Health, and Telemedicine in Medical Education in SSA

\begin{tabular}{lcccll}
\hline Country & Subregion & $\begin{array}{c}\text { No. of } \\
\text { studies }\end{array}$ & $\%$ & $\begin{array}{l}\text { No. of } \\
\text { studies by } \\
\text { subregion }\end{array}$ & \% \\
\hline Cameroon & Central Africa & 01 & 5.6 & 01 & 5.6 \\
\hline
\end{tabular}




\begin{tabular}{llllll}
\hline Kenya & Eastern Africa & 02 & 11.1 & 04 & 22.2 \\
\hline Tanzania & Eastern Africa & 01 & 5.6 & - & \\
\hline Uganda & Eastern Africa & 01 & 5.6 & - & 5.6 \\
\hline Malawi & $\begin{array}{l}\text { South-Eastern } \\
\text { Africa }\end{array}$ & 01 & 5.6 & 01 & 27.8 \\
\hline Botswana & $\begin{array}{l}\text { Southern } \\
\text { Africa }\end{array}$ & 03 & 16.6 & 05 & - \\
\hline $\begin{array}{l}\text { South } \\
\text { Africa }\end{array}$ & $\begin{array}{l}\text { Southern } \\
\text { Africa }\end{array}$ & 02 & 11.1 & - & 11.1 \\
\hline $\begin{array}{l}\text { Sub- } \\
\text { Saharan } \\
\text { Africa }\end{array}$ & SSA & 02 & 11.1 & 02 & $27.8 \%$ \\
\hline Ghana & $\begin{array}{l}\text { Western } \\
\text { Africa }\end{array}$ & 01 & 5.6 & 05 & $100 \%$ \\
\hline Nigeria & Western & 04 & 22.2 & - & 18 \\
\hline Africa & 18 & $100 \%$ & 18 & \\
\hline
\end{tabular}

Table 3 shows that studies on m-learning spanned across nine countries with two studies that were on the state of m-learning in Sub-Saharan Africa in general, without country specification. Southern and western Africa had five studies, eastern Africa produced four, while central Africa and south-eastern Africa had a study each. Based on countries, Nigeria had four studies (22.2\%) which were the highest number of studies followed by Botswana with three (16.6\%). Kenya and South-Africa had two studies each, which is (11.1\%). Tanzania, Uganda, Malawi, and Ghana had one study each (5.6\%). The spread of the studies is in Figure 2.

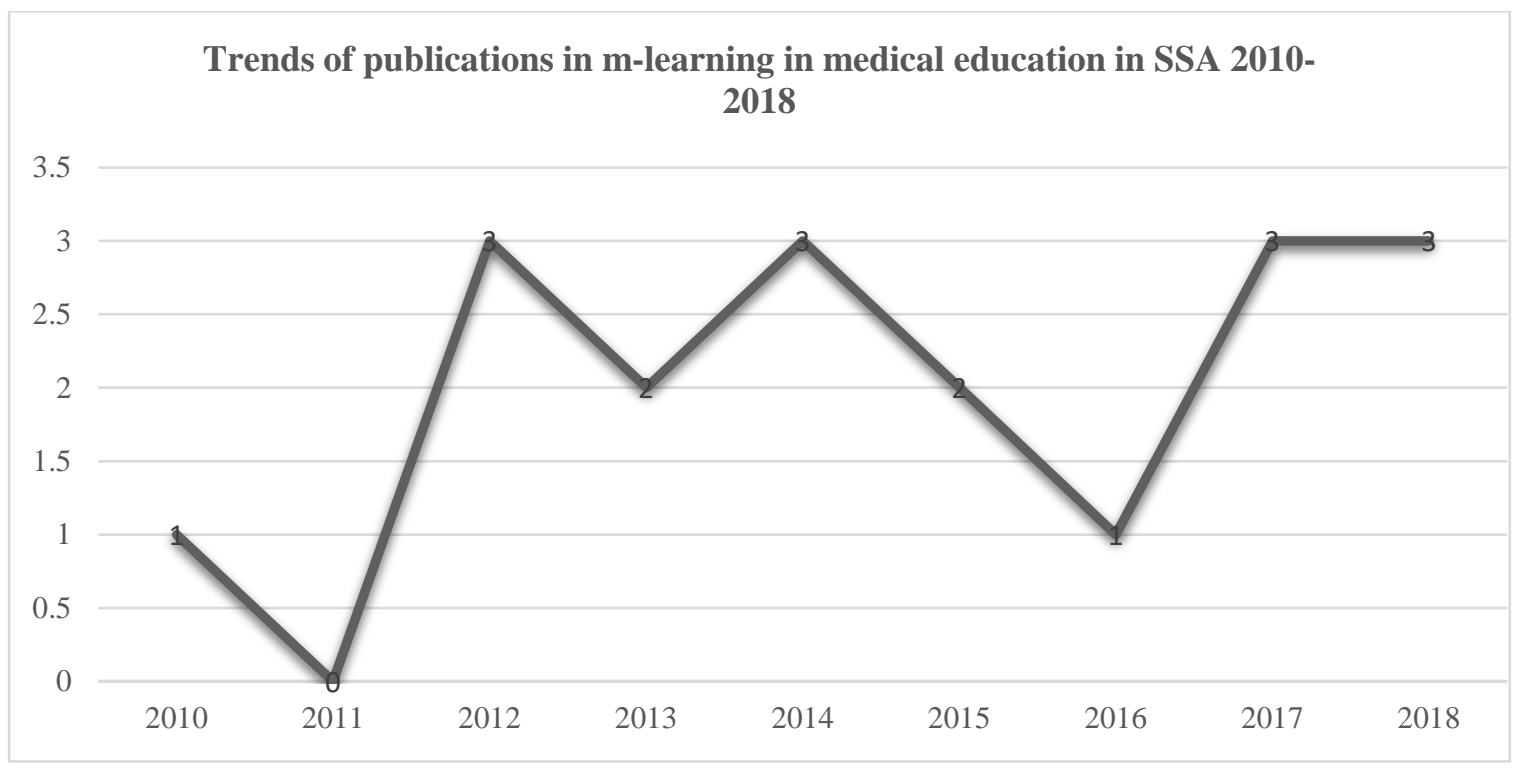

Figure 2. Trends of articles on m-learning in SSA 2010-2018.

The graphical details in Figure 2 show a relative consistency in the number of studies published on a yearly basis between 2010 and 2018. In 2011, there were no studies on m-learning in medical education, but the rest of theyears had two studies, with a maximum of three studies recorded in 2018. In totality, this represents an average of one study per year for m-learning in medical education within the subregion. 


\section{The Methodology Employed in Studies of M-Learning in Medical Education in SSA}

Regarding research question three, the methodologies or approaches employed included; research design, data collection, subjects, sample size, and statistical tools used for the analysis.

\section{Study Design and Instruments}

The aspects of the methodology assessed were the research design and instruments adopted by the various studies, as presented in Table 4.

Table 4

Research Design and Instruments for the Reviews of M-Learning in Medical Education (ME) in SSA

\begin{tabular}{llllll}
\hline Design & $\begin{array}{l}\text { No. of } \\
\text { Studies }\end{array}$ & & \multicolumn{3}{c}{ Instruments } \\
\cline { 4 - 6 } & & & Questionnaires & Interview & $\begin{array}{l}\text { Both } \\
\text { questionnaire } \\
\text { \& interview }\end{array}$ \\
\hline Qualitative & 03 & $16.7 \%$ & $03(16.7 \%)$ & \\
\hline Quantitative & 07 & $38.8 \%$ & & $07(38.8 \%)$ & $05(27.7 \%)$ \\
\hline Mixed Method & 05 & $27.8 \%$ & & $03(16.7 \%)$ \\
\hline $\begin{array}{l}\text { Experimental } \\
\text { (Feasibility/Pilot) }\end{array}$ & 03 & $16.7 \%$ & & \\
\hline Total & 18 & $100 \%$ & & \\
\hline
\end{tabular}

Table 4 shows that a quantitative research design dominated most of the studies as seven (38.8\%) out the total studies employed this research design, followed by the mixed method approach with five (27.8\%), while qualitative and experimental design were the least used design. For data collection, the questionnaire was the most dominant instrument, used in seven studies representing 38.8\%. A mixed method (i.e. survey and interview) was used in five studies (27.8\%) while the least used research design was experimental (16.7\%).

\section{Subjects and Sample Size}

The subjects selected for the studies and their corresponding sample sizes are featured in Table 5.

Table 5

Subjects and Sample Sizes

\begin{tabular}{|c|c|c|c|c|c|}
\hline \multirow{2}{*}{$\begin{array}{l}\text { Subjects } \\
\text { format }\end{array}$} & \multirow{2}{*}{$\begin{array}{l}\text { No. of } \\
\text { studies }\end{array}$} & \multirow[b]{2}{*}{$\%$} & \multicolumn{3}{|c|}{ Sample size } \\
\hline & & & $\leq 100=$ Small & $>150 \leq 250=$ Medium & $>250=$ Large \\
\hline $\begin{array}{l}\text { Medical } \\
\text { doctors } \\
\text { (instructors) }\end{array}$ & 02 & $11.1 \%$ & 01(5.55\%) & - & 01(5.55\%) \\
\hline $\begin{array}{l}\text { Trainee } \\
\text { physicians, } \\
\text { doctors } \\
\text { (interns) } \\
\text { students }\end{array}$ & 05 & $27.8 \%$ & 03(16.7\%) & 01(5.56\%) & 01(5.56\%) \\
\hline $\begin{array}{l}\text { Both } \\
\text { instructors } \\
\text { (doctors) \& }\end{array}$ & 02 & $11.1 \%$ & 01(5.55) & - & 01(5.55\%) \\
\hline
\end{tabular}




\begin{tabular}{|c|c|c|c|c|c|}
\hline $\begin{array}{l}\text { medical } \\
\text { students }\end{array}$ & & & & & \\
\hline $\begin{array}{l}\text { Doctors, } \\
\text { health } \\
\text { professionals } \\
\text { including } \\
\text { nurses } \\
\text { (combined) } \\
\end{array}$ & 06 & $33.3 \%$ & 03(16.65\%) &.- & 03(16.65\%) \\
\hline $\begin{array}{l}\text { Patients \& } \\
\text { institutions } \\
\text { (experimental } \\
\text { studies) }\end{array}$ & $\overline{03}$ & $16.6 \%$ & 02(11.1\%) & - & 01(5.53\%) \\
\hline Total & 18 & $100 \%$ & 10 (55.5\%) & $01(5.5 \%)$ & 07 (38.9\%) \\
\hline
\end{tabular}

Table 5 indicates that six studies (33.3\%) used medical doctors, healthcare workers, and interns/ physician trainees as subjects of their studies, followed by five studies with trainee physicians and doctors only as their subjects. Two studies constituting $27.8 \%$, used medical doctors only as their subjects (i.e. 11.1\%), while another two studies used both instructors (doctors) and medical students (11.1\%). Other studies that focused on medical institutions, in general, were experimental and based on pilot testing. This method constituted three studies (16.6\%) of the total number of studies. With regards to sampling sizes, ten studies used small sample sizes (55.5\%) while seven studies used large samples (38.9\%), and only one study used medium size sample for their research. The results revealed that most of the studies used small sample sizes.

\section{Statistical Tools Employed for the Analysis}

The quality and reliability of research findings lie with the analytical tools used for the analysis of the study. In that respect, this study sought to find out and aggregate the analytical tools used in the studies on m-learning in medical education in SSA as depicted in Table 6.

Table 6

Statistical Tools in the Research and Data Analysis

\begin{tabular}{lcc} 
Statistical tool & No. of studies & $\%$ \\
\hline Thematic/ narrative & 05 & $27.7 \%$ \\
\hline Descriptive & 08 & $44.4 \%$ \\
\hline Correlation & 01 & $5.7 \%$ \\
\hline $\begin{array}{l}\text { Regression/Chi-square/GLMs/ } \\
\text { MANOVA }\end{array}$ & 04 & $22.2 \%$ \\
\hline $\begin{array}{l}\text { Structural equation modelling } \\
\text { (SEM) }\end{array}$ & Nil & $00 \%$ \\
\hline Total & 18 & $100 \%$
\end{tabular}

As shown in Table 6, eight studies (44.4\%) used descriptive statistics, i.e. simple frequencies and percentages to analyse their data. Five studies used thematic and narrative analysis for their data analysis, especially for qualitative data. Four studies employed predictive and group difference analysis tools to analyse their data (22.2\%). The least used statistical tool was a correlation which was featured in only one study (5.7\%).

\section{Effective Factors/Milestones Determining M-Learning in Medical Education in SSA}


In response to research question four of this review, the study catalogued various factors reported across the reviewed studies as determinants or milestones of m-learning use or adoption. Results from the analysis produced ten elements and their frequencies of occurrence as represented in Figure 3.

Determinants of m-learning in Medical Education in SSA

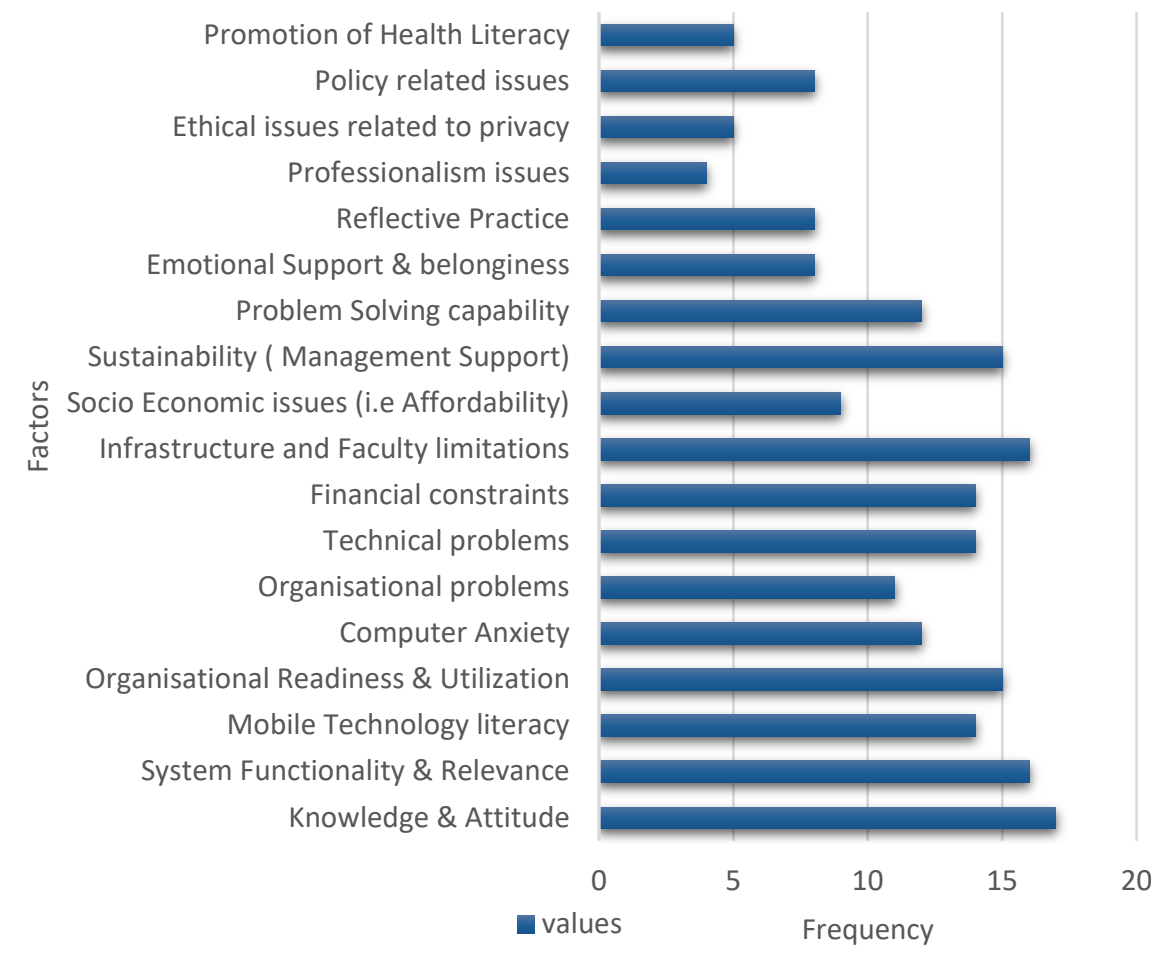

Figure 3. Determinants of m-learning in SSA.

Figure 3 represents the frequency of factors that determine the use and adoption of m-learning in SubSaharan Africa. Knowledge and attitude had the highest rate of occurrence of 17, followed by system functionality, relevance, and infrastructural and faculty limitations with 16. Organisational readiness and sustainability 15, mobile technology literacy, financial constraints, and technical problems had 14, while professionalism and ethical issues related to the use of m-learning had the least frequency of 4 and 5 respectively.

\section{Challenges Involved in M-Learning Implementation in Medical Education in SSA}

The outcome of problems in the reviewed studies is depicted in Figure 4. 


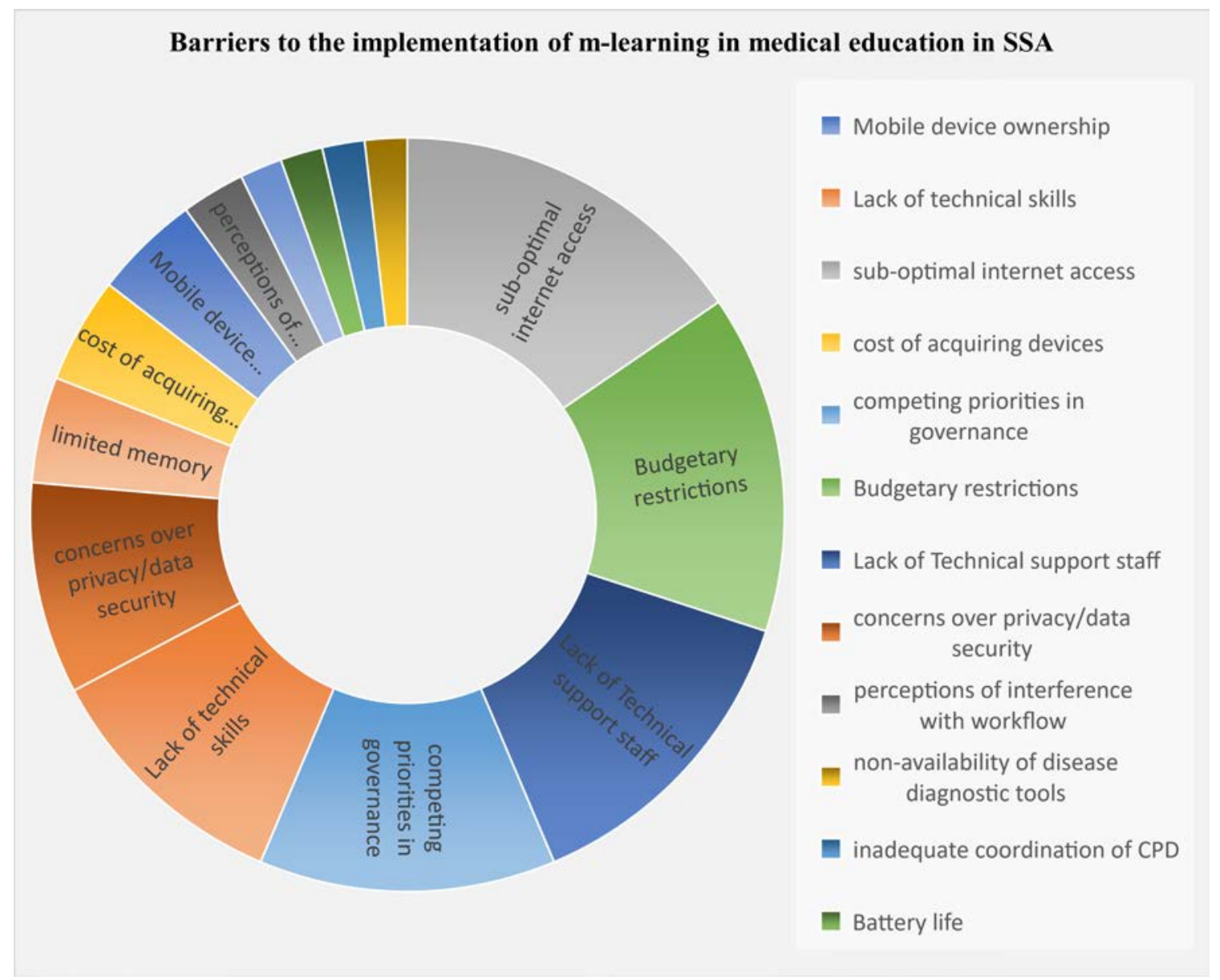

Figure 4. Sunburst chart of barriers to the implementation of m-learning in SSA.

Figure 4 highlights the challenges to effective implementation of m-learning in medical education in Sub-Saharan Africa. These challenges include: mobile device ownership; lack of technical skills; suboptimal Internet access; cost of acquiring the devices; competing priorities in governance; budgetary restrictions; technical staff shortages; concerns over privacy; perception of interference with clinical workflow; absence of disease diagnostic tools; inadequate coordination of continuous professional development; battery life; small screen; and limited memory. Out of this broad range of challenges, 17 studies (94.4\%) reported sub-optimal Internet access as a significant barrier, while 16 studies (88.9\%) reported budgetary restrictions as a major hindrance to implementing m-learning in medical education in SSA. Fifteen studies (83\%) said technical staff shortages was a barrier. Additionally, 14 (77.8\%) reported competing priorities in governance as a determinant factor with 12 studies (66.7\%) reporting a lack of technical skills. The least challenges in the reviewed studies include: battery life $2(11.1 \%)$ and small screen 2 (11.1\%).

\section{Discussion, Recommendations, and Conclusion}

The aggregate of the reviewed studies on m-learning in medical education in Sub-Saharan Africa indicated that western and southern Africa contributed more studies in m-learning in medical education. The outcome was because four studies were from Nigeria, and one was from Ghana, while 
Botswana and South Africa had three studies and two studies respectively. These subregions; southern and western Africa, are home to two of the most economically advanced countries in Africa as corroborated by Okai-Ugbaje, Ardzejewska, and Ahmed (2017) and Bervell and Umar (2017). The authors reported that world bank classification of countries in theregion by income placed South Africa as an upper middle-income country while Ghana, Nigeria, Kenya, Tanzania, Uganda, and Botswana as lower-middle-income countries with potentials for further growth (Bervell \& Umar, 2017). Since the significant determinants of effective implementation of technological innovation are infrastructure, financial constraints and competing priorities, possessing higher income means that the governments have committed enough resources in providing support for Information Technology and ICT resources in Higher Education. Consequently, this has resulted in more projects and research activities in elearning and the integration of technologies in Higher Education, especially in medical education and practice.

Another reason for the seemingly encouraging interest in research on $\mathrm{m}$-learning in medical education in Sub-Saharan Africa is the exponential rise in Internet penetration in the region (Anokwa, 2010). It is also instructive to note the relatively inexpensive features coupled with the affordances of mobile technologies also contributed to facilitating patient care and collaboration. Overall, the need to provide access to health services in remote and resource-constrained communities makes continuous research efforts in mobile technologies in medical education and practice defendable. Authors such as Chen et al. (2012), Feldacker et al. (2017), Pimmer et al. (2014), and Urassa et al. (2018), were all in agreement that $\mathrm{m}$-learning programs have made significant impacts in places deployed. Furthermore, the World Health Organization (2011) reported that the quantum of mobile network penetration in SSA had surpassed infrastructure and Internet deployment. Nonetheless, higher income countries show more e-health activities than low-income countries. These advances may have culminated in the innovative application of mobile technologies to address health needs, thereby making the intersection of networked technology and health in developing countries become of utmost importance.

Instances of these remarkable innovative studies were in Ghana, where Aryee (2014) reported the practical use of mobile phones for inquiring about health concerns, practising teleconsultation, and for scrutinising counterfeit medications. The activity directly contributed to the successes recorded in the Mobile Doctors Network (MDnet) in 2009 (WHO, 2011). In a similar vein, Wasserman (2012) reported a significant increase in medical school enrolment in SSA which prompted the use of m-learning as a solution for providing easy access to learning materials and encouraging interaction amongst nurses in Tanzania. However, to have an effective continuous professional development program that will help in mitigating the impact of chronic diseases such as tuberculosis and HIV, there must be sustainable financial resources to provide the infrastructure that will lead to increased capacity and skills of the healthcare workers (Feldacker et al., 2017).

The results as presented in this study may be considered abysmal against the background that subSaharan Africa comprises of 48 countries out of which only nine states produced the number of reviewed articles (18). This supposedly indicates the low level of m-learning use in medical education in the subregion and holds promise for further research in that domain.

On models and designs adopted in research on m-learning, the review found out that there were no research models or conceptual models used in all the studies included in the report. Models are important because they provide powerful ways to address key information system research problems such as understanding information technology usage (Chin \& Todd, 1995). Also, Borner (as cited in, 
Baltimore, Charo, \& Kevles, 2016) asserts that models of technology and innovation help to inform policy decisions in education, health care, and other sectors which empower experts to make informed recommendations and predictions. Against this backdrop, model-based research will be constructive since m-learning is an attempt to improve the teaching and learning process in medical education, an approach that involves the use of mobile technologies for instructional, collaboration, and remoteaccess to materials for just-in-time learning (Frehywot et al., 2013). However most of the studies in this review dwelled on practical solutions such as testing the effectiveness of smartphone (Android-based) applications with point-of-care programs for seeking medical information (Chang et al., 2012) and expert system developed to ease communication between doctors and health personnel across remote locations (Olajubu et al. 2014).

Regarding research design and instruments used in m-learning in medical education research in SSA, most of the reviewed studies applied the quantitative research design. Although the quantitative design is a standard measure and an excellent way of finalising results in the scientific field, its limitation is not accommodating findings that could augment the analysis Creswell (as cited in Bervell and Umar, 2017). However, a qualitative design was used in three of the studies, while a mixed method design was featured in five of the reviews. The authors are of the view that mixed method research approaches offer better ways to explain and understand the complexities of the organisational, social, and scientific phenomenon.

The study also revealed the use of all health personnel within the health care system as the most recurring subjects in the studies. This is understandably so as the interrelationship that exists between these actors in the implementation of any technology intervention in the health sector is critical to its success.

The dominant statistical tool adopted for data analysis in the studies on m-learning in medical education in SSA was descriptive statistics. The thematic narrative was the next most used statistical tool, and regression and Chi-square analysis appeared in only four studies. As outlined by Trochim (2006), descriptive statistics are used to describe the essential features of the data in a survey by porviding simple summaries about the sample and the measures. Using simple graphical analysis, they form the basis of virtually every quantitative analysis of data (Trochim, 2006). Perhaps, it is the most prevalent in health and medical research because it addresses visible and practical scientific evidence regarding what is or what the data shows or represents. However, relying only on descriptive statistics eliminates important relationships within mobile learning and even further makes it difficult in predicting the occurrence of other variable based on their predictors (Miles, Huberman, \& Saldaña, 2014).

The significant determinants of m-learning in medical education implementation revealed were infrastructure and faculty limitations; competing priorities; budget constraints; system functionality and relevance; sustainability; socio-economic issues (affordability); promotion of health literacy; ethical issues related to privacy; emotional support and belongingness; knowledge and attitude; and mobile technology literacy and technical issues. Some of the studies reported on efforts to satisfy these factors or overcome the constraints. Gupta, Marsden, Oluka, Sharma, and Lucas (2017) suggested that to overcome issues of sub-optimal Internet connectivity (IT infrastructure) and network performance, intervention models like fair usage policy; network monitoring; effective enforcement of access regulations; and the use of user authentication systems should be adopted. For these interventions to 
succeed, there must be international solidarity and public/ private partnerships to tackle the problems of shortage as recommended by Chenault (2011).

Recognising the critical role of evaluation on the success of policy implementation and change management across contexts, the WHO Global Observatory (2011) recommended continual evaluation of health systems, to come up with empirical evidence upon which policymakers, administrators and other stakeholders in SSA, can base their policy decisions. Investigating attitudes towards mobile technology in medical education, Adebara, Adebara, Olaide, Emmanuel, and Olanrewaju (2017), Ibrahim, Salisu, Popoola, and Ibrahim (2014), and Obi et al. (2018) reported participants demonstrated a positive attitude towards the of use mobile technology in medical education and practice. Conversely, this has a substantial effect on the acceptance of the technology and vice versa (Adebara et al., 2017; Ibrahim et al., 2014; Obi et al., 2018). However, the attitude of medical students and physicians or doctors is influenced by some specific factors such as; awareness, skills, training, and availability of the relevant infrastructure (Adebara etal., 2017; Ibrahim et al., 2014; Obi etal., 2018). With this, the success or otherwise of m-learning in medical education implementation in SSA depends on how to overcome the myriads of problems identified by the studies in the review.

Despite the challenges to the integration of mobile learning in health education in SSA, authors such as Pimmer et al. (2014) and Masita-Mwangi et al. (2012) identified the ways in which mobile learning contributes to health education such as; authentic problem solving; reflective practice; realisation of unpredictable teaching situations and lifelonglearning. Mobileand smartphones support a broad range of educational practices in informal and clinical environments, especially for clinical examination and capturing of clinical events. Relating the outcome of their studies, Urassa et al. (2018) assert that mobile learning encourages more interaction in education and enhances self-directed learning. Adjorlolo and Ellingsen (2013) indicate that the use of mobile phones facilitates ICT support in patient care and collaborations that have their foundation on $\mathrm{m}$-learning in health personnel training. This underscores the need for leadership across the Higher Education landscape, especially in medical education in subSaharan Africa, to do a comprehensive evaluation of the existing system. A thorough analysis of the research on ICT and technology-based solutions will inform decisions that will galvanise effort towards improved access and health care delivery at all levels (especially in resource-constrained communities). In furtherance of these objectives, Masika et al. (2015) recommends the public-private-partnership model, which considers the scarcity of resources in most SSA countries.

\section{Recommendations for Future Research}

Based on the findings of the review the following recommendations are proposed:

1. Given that our study revealed simple descriptive statistics as the most used analysis, we suggest that future studies focus on studies in m-learning adoption and acceptance that may reveal the use of advanced statistical tools in medical and healthcare education research in SSA.

2. There is a need for more research in medical education and practice primarily in the use of mobile technologies as only nine countries out of 48 African sub-Sahara nations met the inclusion criteria. Also, future studies should address the limitation of our study by extending the scope to include other African countries and beyond. 


\section{Recommendations for Policy and Practice}

1. Governments across the sub-Sahara region and institutional leadership in Higher Education Institutions should realign their priorities for human capital development by allocating more funds for critical infrastructural provision (that addresses poor bandwidth, sub-optimal Internet access etc.) and training and retraining of the workforce to foster the growth and development of m-learning in medical education and practice in the region.

2. Oyo and Kalema (2014)'s postulated baseline requirements for the adoption of any form of eLearning technology are worth noting here, and include:

- The formation and funding of a hub for the coordination of the e-learning platform (be it $\mathrm{m}$-learning in medical education, or in any other technology-mediated platform);

- Development of contents, curricula, and program accreditation for m-learning;

- The content delivery mechanism for m-learning in ODL;

- Provision of access to computers, the Internet, and mobile technologies and applications; and

- Adequate funding of mobile learning projects.

\section{Conclusion}

This paper reviewed articles on mobile learning research trends and challenges to its implementation in medical education in SSA between 2010 to 2018. It identified the research designs, subjects, sample size, and instruments and statistical tools employed for the analysis in the studies. Additionally, the paper focused on the factors determining m-learning adoption and associated barriers to medical education in SSA. The study provided an overview of the state of the literature in that domain and sought to guide the direction of future studies, policy, and practice. Mtebe and Raphael (2018) opined that the proliferation of mobile phones in SSA and the emergence of fibre optical marine cable and adoption of various electronic learning systems would continue to increase, making the need for effective strategies to leverage these technologies very critical. However, we conclude this discussion anchoring on Traxler (2009)'s view on mobile learning: "mobile learning is uniquely suited to support context-specific and immediatelearning, it is a major opportunity for distance learning since mobile technologies can situate learners and connect learners" (p.18). Mobile learning is indeed an opportunity for addressing the challenges of educational, social, political, and economic development of all resource constrained economies in general and of SSA in particular.

\section{Limitations}

1. The review concentrated on articles written in the English language on mobile learning, mobile health, and Telemedicine based on research in medical education and practice in SSA without considering studies done in other African languages.

2. The review focused on m-learning without considering other aspects of technology intervention in Healthcare systems in Africa. 


\section{Acknowledgements}

The authors acknowledge the contributions of all the authors of the literature used for the review. Authors are also grateful for the PhD sponsorship by Usmanu Danfodiyo University Sokoto and TETfund Nigeria for their support and encouragement. 


\section{References}

Adebara, O., Adebara, I., Olaide, R., Emmanuel, G., \& Olanrewaju, O. (2017). Knowledge, attitude, and willingness to use $\mathrm{m}$-health technology among doctors at a semi-urban tertiary hospital in Nigeria. J ournal of Advances in Medicine and Medical Research, 22(8), 1-10. Retrieved from http:// www.journalrepository.org/ media/journals/JAMMR_64/2017/J ul/Adebara2282017J AMMR33232.pdf

Adjorlolo, S., \& Ellingsen, G. (2013). Readiness assessment for implementation of electronic patient record in Ghana: A case of University of Ghana hospital. J ournal of Health Informatics in Developing Countries 7(2), 128-140.

Retrieved from http:// www.jhidc.org/ index.php/jhidc/ article/ view/ 104

Africa-America Institute. (2015). AAI-SOE-report-2015-final. The State of Education in Africa Report 2015. Retrieved from http:// www.aaionline.org/ wp-content/ uploads/ 2015/ 09/AAISOE-report-2015-final.pdf

Ally, M. (2009). Mobile learning is transforming the delivery of education and training. MIS Quarterly, 3(2), 137-152. https:// doi.org/ 10.1111/j.1467-8535.2007.00809.x

Anokwa, Y. (2010). Delivering better HIV care in sub-Saharan Africa using phone-based clinical summaries and reminders. America, 1-27. Retrieved from http://anokwa.com/publications/2010_UW_Generals_Paper.pdf

Aryee., K. L. (2014). The role of mobile phones in health education for rural communities in Ghana: An exploratory study in digital technologies. Retrieved from https:/ ir.lib.uwo.ca/ etd/ 2030/

Baltimore, D., Charo, R. A., \& Kevles, D. J . (2016). Summit on human gene editing. National Academies of Sciences, 61-69. Retrieved from https:// www.nbp.pl//badania/ seminaria/ 25x2016_2.pdf

Barteit, S., Hoepffner, P., Huwendiek, S., Karamagi, A., Munthali, C., Theurer, A., \&Neuhann, F. (2015). Self-directed e-learning at a tertiary hospital in Malawi-A qualitative Evaluation and Lessons learnt. GMS Zeitschrift für medizinische Ausbildung [GMSjournal for medical education], 32(1). doi: 10.3205/ zma000949

Bediang, G., Stoll, B., Geissbuhler, A., Klohn, A. M., Stuckelberger, A., Nko’o, S., \& Chastonay, P. (2013). Computer literacy and E-learning perception in Cameroon: the case of Yaounde Faculty of Medicine and Biomedical Sciences. BMC Medical Education, 13(1), 57. https:// doi.org/ 10.1186/ 1472-6920-13-57

Bervell, B., \&Umar, I. N. (2017). A decade of LMS acceptance and adoption research in sub-Sahara African Higher Education: A systematic review of models, methodologies, milestones, and main challenges. Eurasia J ournal of Mathematics, Science and Technology Education, 13(11), 7269-7286. https:// doi.org/ 10.12973/ ejmste/ 79444

Biruk, S., Yilma, T., Andualem, M., \&Tilahun, B. (2014). Health professionals' readiness to implement electronic medical record system at three hospitals in Ethiopia: A cross sectional study. BMC medical informatics and decision making, 14(1), 115. https:/ / doi.org/ 10.1186/ s12911-014- 
Chang, A. Y., Littman-Quinn, R., Ketshogileng, D., Chandra, A., Rijken, T., Ghose, S. ... Kovarik, C. L. (2012a). Smartphone-based mobile learning with physician trainees in Botswana. International J ournal of Mobile and Blended Learning, 4(2),114. https:// doi.org/ 10.4018/jmbl.2012040101

Chang, A. Y., Ghose, S., Littman-Quinn, R., Anolik, R. B., Kyer, A., Mazhani, L. ... \& Kovarik, C. L. (2012b). Use of mobile learning by resident physicians in Botswana. Telemedicine and eHealth, 18 (1), 11-13. https:// doi.org/ 10.1089/ tmj.2011.0050

Chen, C., Buch, E., Wassermann, T., Frehywot, S., Mullan, F., Omaswa, F., ...Olapade-Olaopa, E. O. (2012). A survey of sub-Saharan African medical schools. Human Resources for Health, 10(1), 4. https:// doi.org/ 10.1186/ 1478-4491-10-4

Chenault, J . (2011). Investigating and improving medical education and library resources at the Tamale teaching hospital in Northern Ghana : A case report. Kentucky Libraries, 76(2), 16-24. Retrieved from https://ir.library.louisville.edu/faculty/ 11

Chin, W. W., \&Todd, P. A. (1995). On the use, usefulness, and ease of use of structural equation modelling in MIS research: A note of caution. MIS Quarterly, 19(2), 237-246. https:// doi.org/ 10.2307/249690

Creswell, J . W. (2013). Research design: Qualitative, quantitative, and mixed methods approaches. Thousand Oaks, California, US: Sage Publications.

Feldacker, C., Pintye, J ., J acob, S., Chung, M. H., Middleton, L., Iliffe, J ., \& Kim, H. N. (2017). Continuing professional development for medical, nursing, and midwifery cadres in Malawi, Tanzania, and South Africa: A qualitative evaluation. PLoS ONE, 12(10), 1-16. https:// doi.org/ 10.1371/journal.pone.0186074

Frehywot, S., Vovides, Y., Talib, Z., Mikhail, N., Ross, H., Wohltjen, H., ... Scott, J . (2013). E-learning in medical education in resource-constrained low- and middle-income countries. Human Resources for Health, 11(1), 1. https:// doi.org/ 10.1186/ 1478-4491-11-4

Gupta, M., Marsden, S., Oluka, T., Sharma, R., \&Lucas, H. (2017). Lessons learned from implementing E-learning for the education of health professionals in resource-constrained countries. Electronic J ournal of E-Learning, 15(2), 144-155. Retrieved from http:// www.ejel.org/ volume15/issue2

Ibrahim, N. A., Salisu, M., Popoola, A. A., \&Ibrahim, T. I. (2014). Use of smartphones among medical students in the clinical years at a medical school in Sub-Sahara Africa: A pilot study. J ournal of Mobile Technology in Medicine, 3(2), 28-34. https:// doi.org/ 10.7309/jmtm.3.2.5

International Telecommunications Union. (2016). ICT facts and figures 2016.

Retrieved from http:// www.itu.int/ en/ ITUD/Statistics/Documents/facts/ICTFactsFigures2016.pdf 
Kaliisa, R., \& Picard, M. (2017). A systematic review of mobile learning in Higher Education: The African perspective. The Turkish Online J ournal of Educational Technology, 16(1), 1-18. https:// doi.org/ 10.1017/ CBO9781107415324.004

Koole, M. L. (2009). A model for framing mobile learning. In M. Ally (Ed.), Mobile learning: Transforming the delivery of education and training. (1(2), pp. 25-47). Edmonton, Canada: Athabasca University Press. Retrieved from https:// books.google.com.ng/ books?id=Itp60WteuJ sC

Krull, G. E., \& Duart, J . D. (2017). Research trends in mobile learning in Higher Education: A systematic review of articles (2011-2015). The International Review of Research in Open and Distributed Learning, 18(7), 1-23. https:// doi.org/ 10.19173/irrodl.v18i7.2893

Lazarus, L., Sookrajh, R., \& Satyapal, K. S. (2017a). Tablet technology in medical education in South Africa: A mixed methods study. BMJ Open, 7(7), 1-10. https:/ / doi.org/ 10.1136/ bmjopen2016-013871

Lazarus, L., Sookrajh, R., \& Satyapal, K. S. (2017b). Tablet technology in medical education in South Africa: A mixed methods study. BMJ Open, 7(7), 1-10. https:/ / doi.org/ 10.1136/ bmjopen2016-01387

Masika, M. M., Omondi, G. B., Natembeya, D. S., Mugane, E. M., Bosire, K. O., \& Kibwage, I. O. (2015). Use of mobile learning technology among final year medical students in Kenya. Pan African Medical J ournal, 21, 1-12. https:// doi.org/ 10.11604/ pamj.2015.21.127.6185

Masita-Mwangi, M., Mwakaba, N., Ronoh-Boreh, F., \& Impio, J . (2012). Building a case for mlearning in Africa. Proceedings of the 2012 ACM Annual Conference Extended Abstracts on Human Factors in Computing Systems Extended Abstracts - CHI EA '12, 521. https:/ doi.org/ 10.1145/ 2212776.2212827

Miles, M. B., Huberman, M. A., \& Saldaña, J . (2014). Qualitative data analysis. A methods sourcebook. Zeitschrift Für Personalforschung [J ournal For Personal Research], 28(4), 485-487. https:// doi.org/ 10.1136/ ebnurs.2011.100352

Moher, D., Liberati, A., Tetzlaff, J ., Altman, D. G., \& Prisma Group. (2009). Preferred reporting items for systematic reviews and meta-analyses: the PRISMA statement. PLoS Medicine, 6(7), e1000097. https:// doi.org/ 10.1371/journal.pmed.1000097

Mtebe, J . S., \& Raphael, C. (2018). Key factors in learners' satisfaction with the e-learning system at the University of Dar es Salaam, Tanzania. Australasian J ournal of Educational Technology, 34(4), 107-122. https:// doi.org/ 10.14742/ ajet.2993

Naismith, L., Lonsdale, P., Vavoula, G., \& Sharples, M. (2004). Literature review in mobile technologies and learning. Educational Technology, 11, 1-25. https:/ / doi.org/ ISBN:09548594-1-3

Obi, I. E., Charles-Okoli, A. N., Agunwa, C. C., Omotowo, B. I., Ndu, A. C., \&Agwu-Umahi, O. R. (2018). E-learning readiness from perspectives of medical students: A survey in Nigeria. 
Nigerian J ournal of Clinical Practice, 21(3), 293-300.

https:// doi.org/ 10.4103/ njcp.njcp_108_17

Okai-Ugbaje, S., Ardzejewska, K., \&Ahmed, I. (2017). A systematic review of mobile learning adoption in Higher Education: The African perspective. I-manager's J ournal on Mobile Applications and Technologies, 4(2), 1. doi: 10.26634/jmt.4.2.13830

Olajubu, E. A., Odukoya, O. H., \&Akinboro, S. A. (2014). LWAs computational platform for econsultation using mobile devices: Cases from developing nations. Technology and Health Care, 22(4), 561-571. https:// doi.org/ 10.3233/ THC-140828

Organisation for Economic Co-operation and Development (OECD) (2009). Teaching practices, teachers' beliefs and attitudes: Creating effective teaching and learning environments: first results from TALIS. OECD. https:// dx.doi.org/ 10.1787/9789264068780-6-en

Oyo, B., \& Kalema, B. M. (2014). Massive open online courses for Africa by Africa. The International Review of Research in Open and Distributed Learning, 15(6), 1-13. https:// doi.org/ 10.19173/irrodl.v15i6.1889

Pimmer, C., Brysiewicz, P., Linxen, S., Walters, F., Chipps, J ., \& Gröhbiel, U. (2014). Informal mobile learning in nurse education and practice in a remote areas: A case study from rural South Africa. Nurse Education Today, 34(11), 1398-1404. https:// doi.org/ 10.1016/j.nedt.2014.03.013

Traxler, J. (2009). The current state of mobile learning. In M. Ally (Ed.), Mobilelearning: Transforming the delivery of education and training (Vol. 1, pp. 9-24). Edmonton, AB: Athabasca University Press.

Trochim, W. M. K. (2006). The research methods knowledge base (2nd ed.). Cincinnati, OH: Atomic Dog Publishing. Retrieved from https:// doi.org/ 10.2471/BLT.05.029181

Tsinakos, A., \&Ally, M. (2013). Global mobile learning implementations and trends. Academia.Edu. Retrieved from http:// www.academia.edu/download/36240447/global_Mobile_Learning.pdf\#page $=31 \%$

Urassa, D., Chaya, P., \& Pilot, J . (2018). Addressing knowledge gaps among nurses in healthcare in Tanzania: Use of m-learning platforms in Tanzania. Global J ournal of Human Social Science 18(1), 54-61.

Witt, R. E., Kebaetse, M. B., Holmes, J . H., Ryan, L. Q., Ketshogileng, D., Antwi, C., ... Nkomazana, O. (2016a). The role of tablets in accessing information throughout undergraduate medical education in Botswana. International J ournal of Medical Informatics. 88, 71-77. https:// doi.org/ 10.1016/j.ijmedinf.2016.01.006

World Health Organization. (2011). M-Health: New horizons for health through mobile technologies. Observatory, 3, 66-71. https:// doi.org/ 10.4258/ hir.2012.18.3.231 
Yunusa, A. A., \&Dalhatu, I. I. (2014). Blended learning technique: Rethinking pedagogical approaches in sandwich / B.Ed art-time degree programmes in Nigerian universities. International J ournal of Topical Issues in Education, Maiden Edition, 58-68. Retrieved from http:// oer.udusok.edu.ng:8080/xmlui/ handle/ 123456789/781

\section{Athabasca}

University

(c) ( 